\title{
BUCKLING OF SLENDER COMPOSITE CONCRETE-FILLED STEEL COLUMNS
}

\author{
C. Douglas Goode ${ }^{1}$, Artiomas Kuranovas ${ }^{2}$, Audronis Kazimieras Kvedaras ${ }^{3}$ \\ ${ }^{1}$ University of Manchester, Manchester, M13 9PL, UK \\ ${ }^{2,3}{ }^{3}$ Vilnius Gediminas Technical University, Sauletekio al. 11, LT-10223 Vilnius, Lithuania \\ E-mails: ${ }^{1}$ cdgoode@ukonline.uk; ${ }^{2}$ artiomas.kuranovas@vgtu.lt; ${ }^{3}$ audronis-kazimieras.kvedaras@vgtu.lt
}

Received 30 Oct. 2009; accepted 11 Feb. 2010

\begin{abstract}
The paper presents the analysis of the experimental data of 1817 on concrete-filled steel tubes - CFSTs. These results are compared with the predicted results of the load-bearing capacity of calculations of slender elements according to the methods suggested by Eurocode 4. The following types of tested CFSTs were analysed: circular and rectangular hollow section stub and long columns fully filled with concrete, which were with or without applied moments at the ends of specimen. During the results obtained in the result of the tests on the load bearing capacity for circular concrete-filled steel tubular columns correspond with the calculated values based on methods presented by Eurocode 4. The experimental values of load bearing capacity for members of concrete-filled rectangular hollow sections agree very well with the theoretical values where the concrete cylinder strength is below $75 \mathrm{~N} / \mathrm{mm}^{2}$. The analysis demonstrated that preloading of concrete-filled hollow section members does not influence the load bearing capacity.

This paper also presents the examination of stress state distribution for concrete-filled hollow section members, influence of concrete preloading and of longitudinal stress strain curves.
\end{abstract}

Keywords: concrete-filled steel columns, buckling, slenderness, load-bearing capacity, Eurocode 4, analysis, comparison, test results.

\section{Introduction}

Steel structural hollow sections are the most efficient of all the structural sections in resisting compression load. And filling these sections with plain concrete significantly increases load-bearing capacity. CFST columns have a number of advantages as follows: a) it combines tension properties of steel and compression properties of concrete and provides the hollow steel sections with greater strength and stiffness, b) the confinement of concrete by steel enhances failure strength of concrete, c) column size may be reduced more than necessary for pure steel or RC column and provide greater floor area for use, d) the steel tube provides the permanent formwork for concrete, e) steel tube column can be erected rapidly for a number of storey heights, allowing to add floors before filling tubes with concrete, f) good seismic resistance because of good ductility and high energy absorbing properties, etc. (Kvedaras et al. 2006, 2009; Partaukas and Bareisis 2009; Benzaid et al. 2008; Soundararajan et al. 2008; Kuranovas et al. 2007; Goode 2007; Kuranovas and Kvedaras 2007; Kudzys et al. 2006; Kuranovas 2006; Eurocode 4 2005; Han et al. 2004; Baochung and Hiroshi 2003; Gopal and Manoharan 2003; Han and Yao 2002, 2003; Han and Yang 2003; Chung et al. 2001; Han 2000; DL/T5085 1999; Zhang and Zhong 1999; Zhong 1999).

The main disadvantage is the degradation of steel properties when exposed to fire, but these elements may be protected by spraying fire retardants to outer surface of the steel tube or by using plasterboard and rock-wool insulation. Furthermore, load-bearing capacity under fire may be improved by using internal reinforcement bars.

Different approaches and design philosophies were adopted in different design codes of different countries. But still in present time it is a lack of information for designers: investigations, test results, FEM and structural analyses are necessary to derive more precise and evaluating safer methods for such type elements. That's why C. D. Goode started collecting data for database, analysed it and proposed new suggestions how to predict more precisely load-bearing capacity of various type CFST elements under various type loading.

\section{Codes and test data}

Different limitations on the compressive strength of concrete, steel yield strength, diameter-to-thickness ratio; steel ration and confining coefficient are prescribed in different codes (Xinbo et al. 2006). These limitations are compared in Table 1 (Kuranovas et al. 2009); where $\xi=1,5 A_{a} f_{a y} / A_{c} f_{c k}, f_{c k}$ is the $150 \mathrm{~mm}$ cube compressive strength of concrete; $f_{a y}$ - is the yield strength of steel tube, $A_{a}, A_{c}$ are areas of steel tube and concrete core respectively, $a_{a}$ is steel ratio; and $E$ is the elasticity modulus of steel tube. 
Table 1. Comparison of the limitations in different codes

\begin{tabular}{|c|c|c|c|}
\hline Item & $\begin{array}{c}\text { CHN-JCJ } \\
01-89\end{array}$ & CHN CECS & $\begin{array}{c}\text { CHN-DL/T } \\
5085\end{array}$ \\
\hline$f_{c k}$ & $30 \sim 50$ & $30 \sim 80$ & $30 \sim 80$ \\
\hline$f_{a y}$ & 235 345 & $235 \sim 420$ & 235 390 \\
\hline$D / t_{a}$ & $\sim$ & $20 \sim 90 \sqrt{235 / f_{a y}}$ & $20 \sim 100$ \\
\hline$a_{a}$ & $0,04 \sim 0,16$ & - & $0,04 \sim 0,20$ \\
\hline$\xi$ & - & $0,03 \sim 0,3$ & - \\
\hline Item & $\begin{array}{c}\text { AISC- } \\
\text { LRFD(99) }\end{array}$ & Eurocode 4 & JAN-AIJ(97) \\
\hline$f_{c k}$ & $26 \sim 65$ & $25 \sim 60$ & \\
\hline$f_{a y}$ & $\leq 415$ & 235 355 & \\
\hline$D / t_{a}$ & $\leq \sqrt{8 E / f_{a y}}$ & $\leq 90 \sqrt{235 / f_{a y}}$ & $\leq 35280 / f_{a y}$ \\
\hline$a_{a}$ & $\geq 0,04$ & - & - \\
\hline$\xi$ & - & - & - \\
\hline
\end{tabular}

The limitations and conditions for composite columns and composite compression members according to EC4 are: a) the steel grade should be S235 to S460, b) concrete of strength classes C20/25 to C50/60, c) local buckling can be neglected if $t>h /\left(52 \sqrt{235 / f_{y}}\right)$ and $t>D /\left(90 \sqrt{235 / f_{y}}\right)$ for columns of circular and rectangular cross section respectively.

Overall buckling is allowed for in the EC4 by introducing a buckling factor $\chi$ related to the relative slenderness $\bar{\lambda}$ by the European buckling curve:

$$
\chi=1 /\left(\varphi+\sqrt{\left(\varphi^{2}-\bar{\lambda}^{2}\right)}\right),
$$

where: $\varphi=0.5 \cdot\left(1+\alpha(\varphi-0.2)+\bar{\lambda}^{2}\right)$ and $\bar{\lambda}=\sqrt{N_{P l, R d} / N_{c r}}$, $\alpha=0.21$ - for any added reinforcement being $\leq 3 \%$ and $\alpha=0.34-$ for $3 \%<\rho_{s} \leq 6 \%$;

$\rho_{s}=100 \times A_{a} / A_{c}$;

$N_{P l, R d}=A_{a} f_{y, d}+A_{c} f_{c d}+A_{s} f_{f s d}$ - plastic compres-

sion resistance;

$N_{c r}=\pi^{2}(E I)_{e f f} / L^{2}-$ the elastic critical load;

$(E I)_{\text {eff }}=E_{a} I_{a}+E_{s} I_{s}+0.6 E_{c m} I_{c}$.

When columns are loaded by end moment two methods of analysis can be applied:

1. Simplified method, where the second-order effects are allowed for by multiplying the first-order applied moments by a factor ' $k$ ';

2. More precisely method, where the second order effect is analysed.

For columns with equal end moments ' $k$ ' is given by:

$$
k=1,10 /\left(1-\left(N_{u} / N_{c r, e f f}\right)\right) \geq 1.00 \text {. }
$$

In the simplified method the calculated moment resistance has been divided by the ' $k$ ' factor to compare with the test result (rather than factoring the test result by ' $k$ ') and the failure load predicted by the code is compared with the test result at the same axial load/moment ratio as was used in the test. Fig. 1 illustrates this where the Eurocode 4 curve allows for slenderness $(\chi)$, the steel grade factor $\alpha_{M}$, and the ' $k$ ' factor. Factor $\alpha_{M}$ has been taken as 0.9, when steel yield strength in the test was less than $420 \mathrm{~N} / \mathrm{mm}^{2}$ and 0.8 , when greater than this.

Thus in the EC 4 curve $M_{E C A}=\chi \times \alpha_{M} \times M / k$. Eurocode 4 states that second-order effects need not be considered and that when the applied load divided by the elastic critical load is less than 0.1 , ' $k$ ' may be taken as unity.

This results in a 'step' in the interaction diagram as when $N / N_{c r, e f f}<0.1$ then $k=1$ but when $N / N_{c r, e f f}=$ 0.1 then $k=1.22$. Test results by Matsui et al. are also

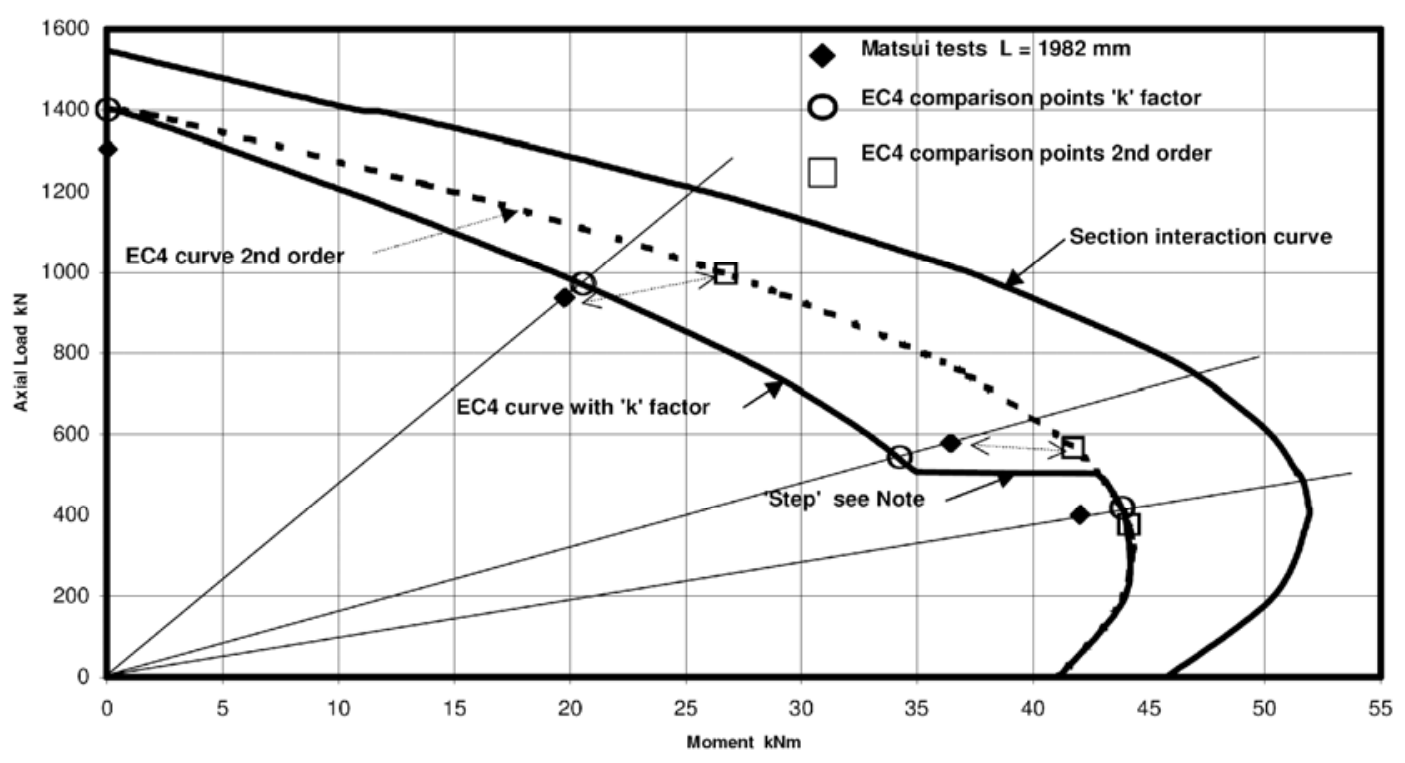


Fig. 1. Typical axial load-moment interaction curve. Note: The 'step' in the Eurocode 4 curve is because of that 'second-order effects need not be considered when $N_{E d} / N_{c r, e f f}<0.1$ the factor ' $k$ ' is unity but for $N_{E d} / N_{c r, e f f}=0.1$ ' $k$ ' $=1.22$ 
shown (Goode 2009). When the 'second order' method is used the lateral deflection of the column at mid-height caused by the end moment was added to the end eccentricity of the load to give the second-order moment and it is the load at this moment on the second-order curve which is compared to the failure load of the column.

In this paper data of results were used to form website database (http://web.ukonline.co.uk/asccs2) (Eurocode 4 2005), which collects together information for 1819 tests of CFSTs and compares the test results with EC4; some typical graphs are also included into this paper.

The data collected in the database is subdivided into "long" ( $L / D(B)>4$ ) columns of "circular" and "square" cross-section (Fig. 2).
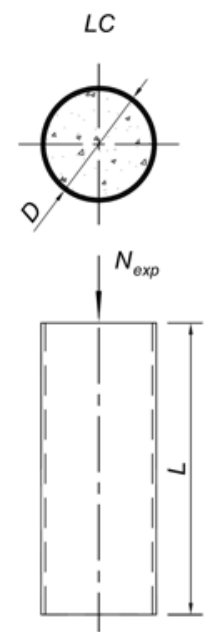

a)
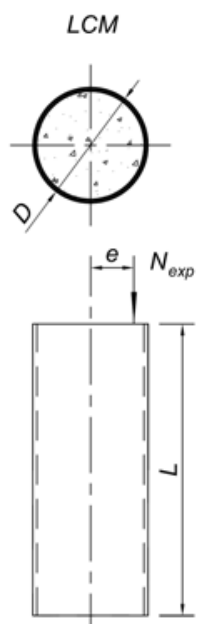

b)

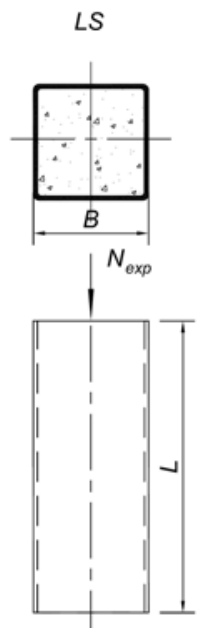

c)

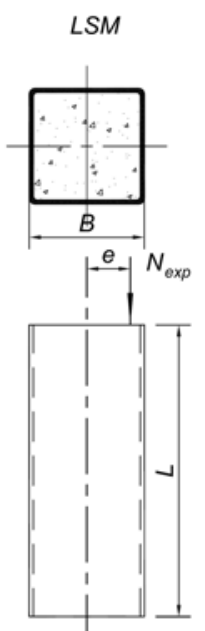

d)
Fig. 2. Long CFST slenderness columns $L / D(B)>4$ :

a) circular CFST with no moment, b) circular with moment, c) square CFST with no moment, d) square CFST with moment

The information required and reported for each test is: outer diameter $(D)$ if circular cross-section, or breath $(B)$ and depth $(H)$ if rectangular one; the thickness $\left(t_{a}\right)$ of the steel tube; the steel properties $\left(f_{a y}\right)$ and, for slender columns, modulus of elasticity ( $E_{a}$ ); the concrete properties (concrete yield strength ( $\left.f_{c y l}\right),\left(f_{c k}\right.$ in Goode 2008) and, for long columns, its secant modulus of elasticity $\left(E_{c}\right)$ to $\left.0,4 f_{c k}\right)$ ); the length ( $L$ ) of the column; the maximum load achieved by the column in test $\left(N_{u}=\right.$ Test failure load). For columns with an end moment the initial eccentricity of load at the top $\left(e_{t}\right)$ and bottom $\left(e_{b}\right)$ is required.

Dispersions of EC4 vs. test and ratio test/EC4 vs. concrete strength for LS and LSM are presented in Figs 7-8 and 9-10 respectively.

Summary results of LC, LCM, LS and LSM are presented in Table 2 (Yamamoto et al. 2000), where it can be seen that the average values of test/EC 4 for each type of column are higher than Eurocode 4 predicts.

Dispersions EC4 vs. test and ratio test/EC4 vs. concrete strength for slenderness elements are shown in Figs 3-10.

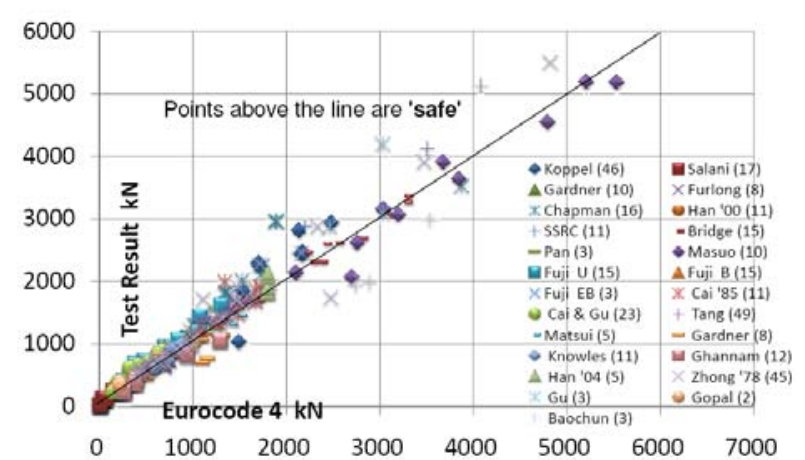

Fig. 3. Tests results of LC concrete-filled steel columns compared with calculations according to (Goode 2008)

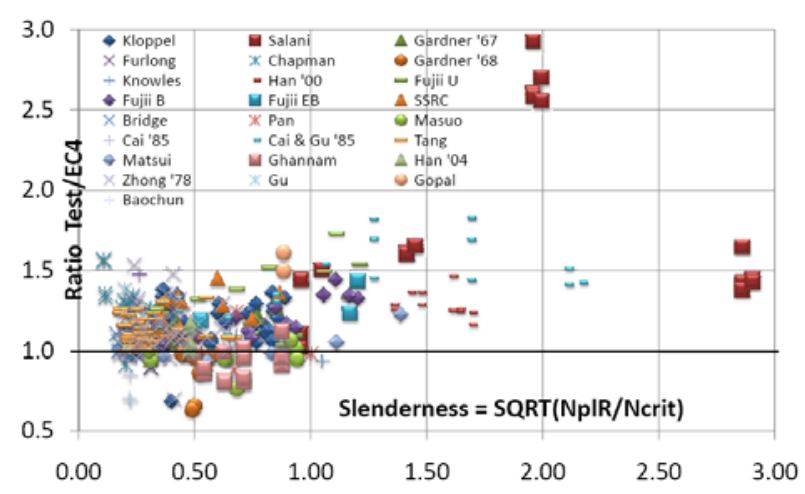

Fig. 4. Ratio test/EC4 vs. slenderness of LC concrete-filled steel columns

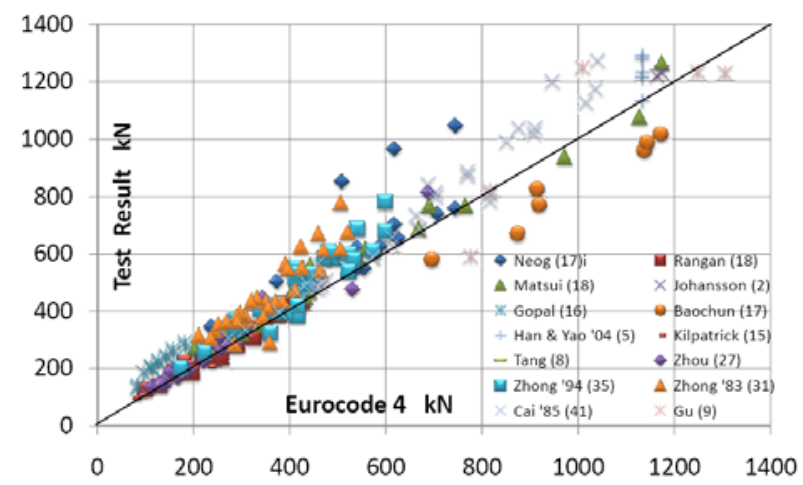

Fig 5. Tests results of LCM concrete-filled columns compared with calculations according to (Goode 2008)

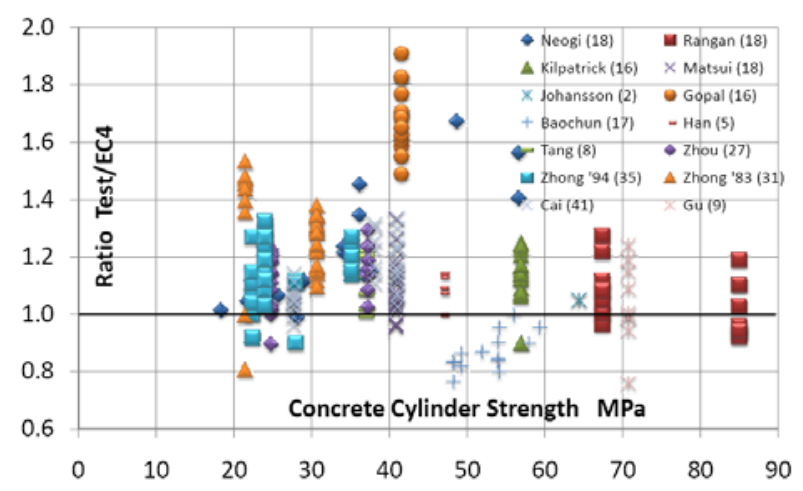

Fig. 6. Ratio Test/EC4 vs. concrete cylinder strength of LCM concrete-filled steel columns 


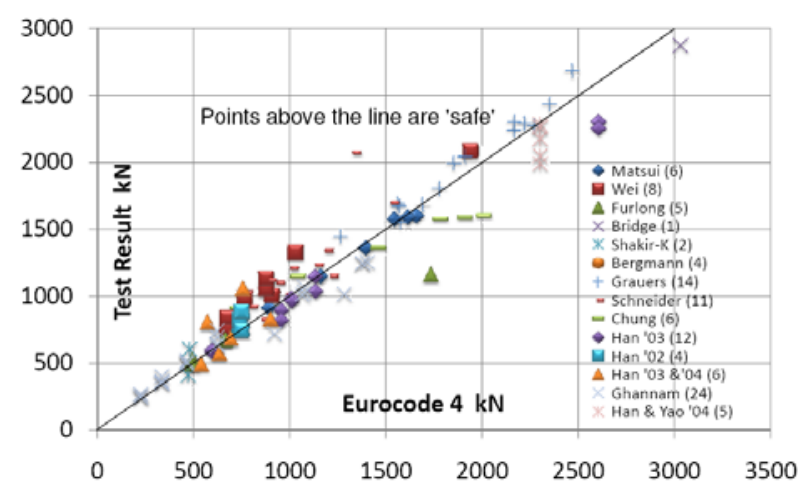

Fig. 7. Tests results of LS concrete-filled steel columns compared with calculations according to (Goode 2008)

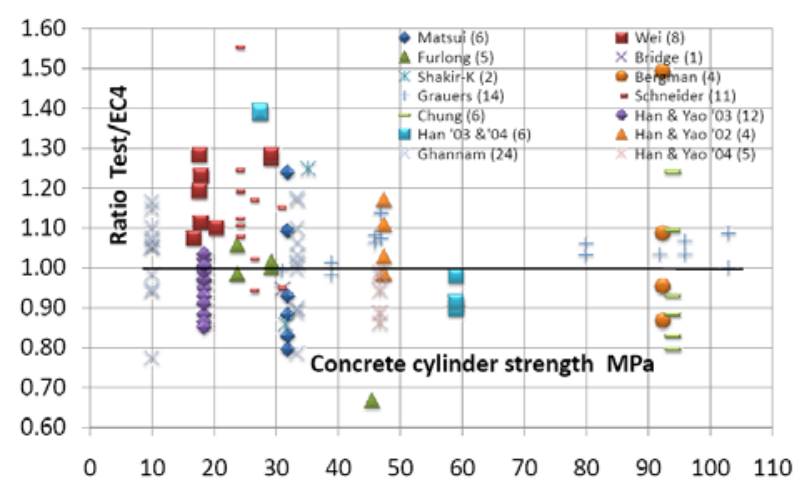

Fig. 8. Ratio test/EC4 vs. concrete strength for LS concretefilled steel columns

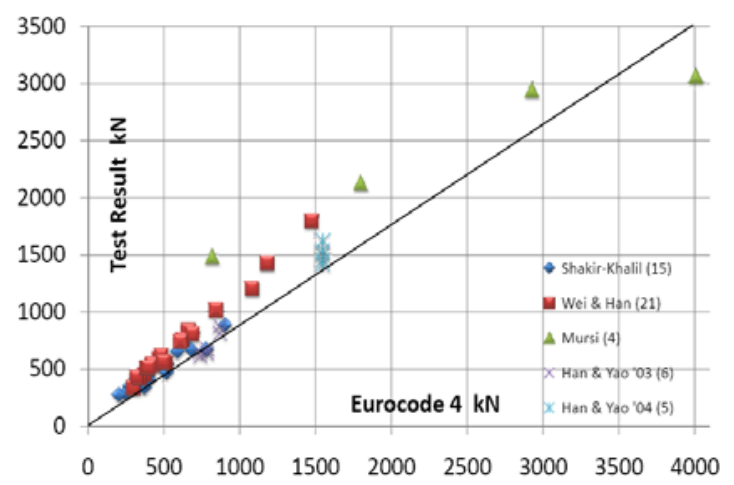

Fig. 9. Tests results of LSM concrete-filled steel columns compared with calculations according (Goode 2008)

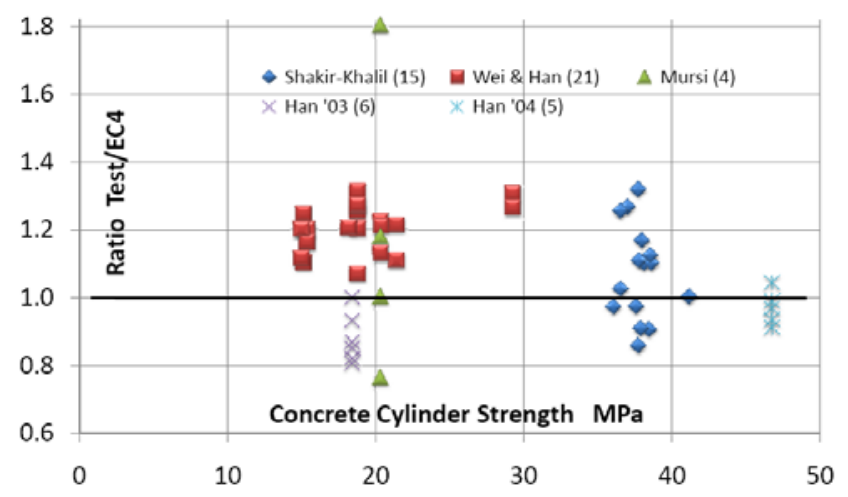

Fig. 10. Ratio test/EC4 vs. concrete cylinder strength of LSM concrete-filled steel columns
The 'failed tests' column of Table 2 shows the percentage of all tests failed before reaching the resistance calculated by EC4 methods.

The last column shows this percentage for the columns, which met all conditions indicated in Eurocode 4. Table 3 (Yamamoto et al. 2000) shows a comparison between average test/EC 4 ratio for different concrete strengths and also the local buckling criteria for the different types of column. For LC type of concrete-filled steel column, there occurred few 'unsafe' results, when the concrete cylinder strength was outside 20 to $50 \mathrm{~N} / \mathrm{mm}^{2}$ cylinder strength permitted by Eurocode 4 than when within this range. For the long square concrete-filled columns, a decrease in the test/EC4 ratio may be observed after high strength concrete has been used for the LCM type.

For circular section columns with an applied end moment, the simplified ' $k$ ' factor method and the 'second order' analysis showed very similar results; see Fig. 11 (Yamamoto et al. 2000). However, for rectangular columns the second order analysis predicted, in general, lower (safer) failure loads than the ' $k$ ' factor method and often much lower than achieved during the tests. Note that about $17 \%$ of all the circular and rectangular tests failed below their predicted failure load. The average test/EC 4 ratio for the 1027 tests analysed in this paper was 1.14 demonstrating standard deviation of 0.114 .

\section{Analysis of other type structures and loadings}

\section{Hollow Sections}

The 76 hollow circular section and the 24 hollow square, 8-sided or 16-sided section columns without bending behaved in a similar way to the solid sections when allowance was made for the hole. The average test/EC 4 ratios were 1.22 for the circular sections and 1.16 for the other sections.

\section{Preload and Sustained Load}

Pre-load (up to $60 \%$ of the capacity of the steel) on the steel tube before filling with concrete seems to have no effect on the strength; the average test/ EC 4 for the 23 circular columns (11 short and 12 long) being 1.15 (Standard deviation 0.123 ) and for the 19 rectangular columns (10 short and 9 long) being 1.03 (Standard deviation 0.099). The eight tests, which sustained an average load of between $53 \%$ and $63 \%$ of their capacity for 120 or 180 days before being loaded to failure, carried a slightly higher load before failing (average test/EC $4=1.25$ ) than their six comparison tests without sustained load (average test/EC 4 = 1.08).

Yamamoto (2000) and Zhang et al.(2007) tested short circular concrete specimens with steel encasing the concrete and the axial load applied only to the concrete and not to the steel. Their results show that stub columns so loaded were able to sustain a higher load (19 tests test/EC $4=1.13$ ) than similar sections where the load was applied uniformly over both steel and concrete (15 tests test/EC $4=1.03$ ). 
Table 2. Summary of results for each type of column

\begin{tabular}{|c|c|c|c|c|c|c|c|}
\hline \multirow{3}{*}{\multicolumn{2}{|c|}{ Type of column }} & \multirow{3}{*}{$\begin{array}{l}\text { NO. OF } \\
\text { Tests }\end{array}$} & \multirow{3}{*}{$\begin{array}{c}\text { AVE } \\
\text { Test/EC4 }\end{array}$} & \multirow{3}{*}{$\begin{array}{l}\text { ST. DEV. } \\
\text { of Test/EC4 }\end{array}$} & \multicolumn{3}{|c|}{ \% where Test/EC4 $<1$} \\
\hline & & & & & \multirow{2}{*}{ Failed tests } & \multicolumn{2}{|c|}{ Tests which satisfy EC4 } \\
\hline & & & & & & $\%<1$ & $\%<1$ \\
\hline & $\mathrm{LC}$ & 369 & 1.17 & 0.148 & $16 \%$ & 306 & $11 \%$ \\
\hline \multirow[t]{2}{*}{ LCM } & \multirow{2}{*}{$\begin{array}{l}\text { ' } k \text { ' factor method } \\
2^{\text {nd }} \text { order analysis }\end{array}$} & 254 & 1.15 & 0.111 & $16 \%$ & 198 & $10 \%$ \\
\hline & & 254 & 1.15 & 0.119 & $22 \%$ & 198 & $18 \%$ \\
\hline & LS & 212 & 1.06 & 0.097 & $35 \%$ & 76 & $30 \%$ \\
\hline \multirow[t]{2}{*}{ LSM } & \multirow{2}{*}{$\begin{array}{l}\text { ' } k \text { ' factor method } \\
2^{\text {nd }} \text { order analysis }\end{array}$} & 96 & 1.11 & 0.098 & $18 \%$ & 26 & $19 \%$ \\
\hline & & 96 & 1.20 & 0.148 & $11 \%$ & 26 & $4 \%$ \\
\hline & Totals & 1027 & 1.14 & 0.120 & $20 \%$ & 830 & $15 \%$ \\
\hline
\end{tabular}

Table 3. Comparison of Test/EC4 for different concrete strengths and for local buckling criteria

\begin{tabular}{|c|c|c|c|c|c|c|c|c|c|c|c|c|}
\hline \multirow{2}{*}{$\begin{array}{l}\text { Type of } \\
\text { column }\end{array}$} & \multicolumn{2}{|c|}{$f_{c y l} \leq 50 \mathrm{~N} / \mathrm{mm}^{2}$} & \multicolumn{2}{|c|}{$f_{c y l}>60 \mathrm{~N} / \mathrm{mm}^{2}$} & \multicolumn{2}{|c|}{$f_{c y l}>75 \mathrm{~N} / \mathrm{mm}^{2}$} & \multicolumn{3}{|c|}{$\begin{array}{l}\text { Local buckling criteria } \\
\text { satisfied }\end{array}$} & \multicolumn{3}{|c|}{ Local buckling 'likely' } \\
\hline & Ave & $\%<1$ & Ave & $\%<1$ & Ave & $\%<1$ & No & Ave & $\%<1$ & No & Ave & $\%<1$ \\
\hline $\mathrm{LC}$ & 1.19 & 14 & 1.08 & 29 & 1.00 & 63 & 334 & 1.19 & 14 & 35 & 1.06 & 37 \\
\hline LR & 1.05 & 40 & 1.09 & 26 & 1.04 & 35 & 130 & 1.07 & 32 & 82 & 1.05 & 40 \\
\hline LCM & 1.18 & 10 & 1.05 & 34 & 1.01 & 56 & 255 & 1.15 & 16 & none & & \\
\hline LRM & 1.09 & 31 & 1.10 & 11 & 0.98 & 75 & 60 & 1.14 & 13 & 65 & 1.03 & 42 \\
\hline
\end{tabular}

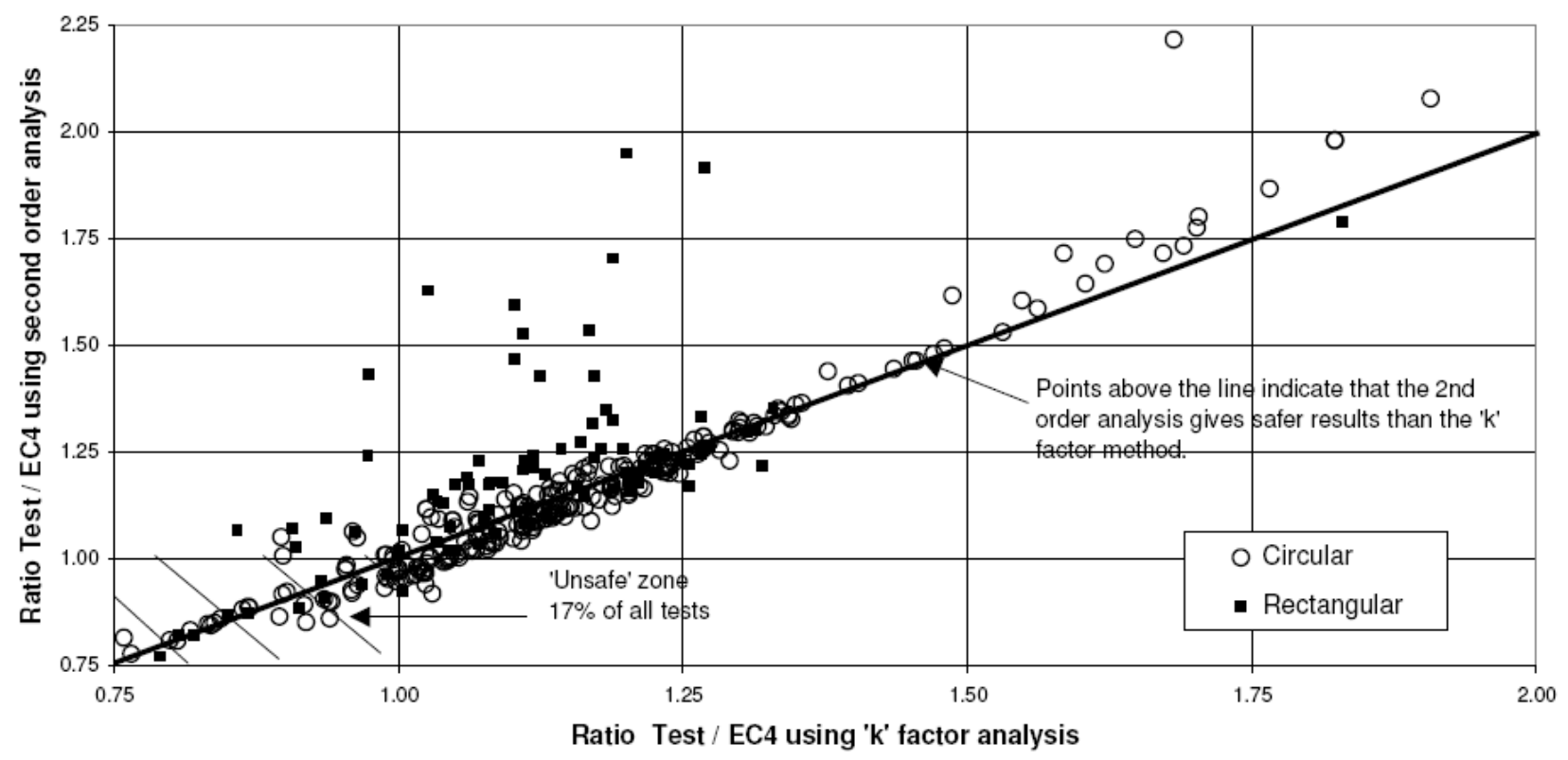

Fig. 11. Columns with moment; comparison of ' $k$ ' factor analysis with 2nd order analysis 


\section{Biaxial Bending}

Only 11 tests on rectangular columns with biaxial bending are reported and these all failed at much higher loads than predicted by Eurocode 4, average test/EC 4 was 1.52. The Code uses a straight line interaction for the bending resistance between the two axes with an additional safety factor $\alpha_{M}$, (with $\alpha_{M}$ as 0.9 for steel grades S235 to S355 and 0.8 for steel grades S420 and S460). Using an elliptical interaction between the moments about the two axes and omitting this additional safety factor, i.e. $\alpha_{M}=1$, gives much closer agreement with the test failure load, an average test/prediction of 1.20 for these 11 tests (Goode 2008, 2009).

\section{Summary and future perspectives}

Eurocode 4 predicts safe methods of strength evaluation for slender LC and LCM concrete-filled columns and could be safely used for concrete with cylinder strength up to $100 \mathrm{~N} / \mathrm{mm}^{2}$. And C.D. Goode's opinion that for circular section columns the Code limitation on concrete cylinder strength could be safely extended to $75 \mathrm{~N} / \mathrm{mm}^{2}$.

For rectangular section CFST columns Eurocode 4 should be used with caution, when the concrete cylinder strength is greater than $75 \mathrm{~N} / \mathrm{mm}^{2}$ as the failure load in the majority of tests when $f_{c y l}>75 \mathrm{~N} / \mathrm{mm}^{2}$ was less than that predicted by the EC4 approach (Note: EC4 limits the concrete strength to $50 \mathrm{~N} / \mathrm{mm}^{2}$ ).

C.D.Goode states that the concrete strength limitation for rectangular section columns could be safely extended to $60 \mathrm{~N} / \mathrm{mm}^{2}$. When higher strength concrete is used, its cylinder strength should be factored by 0.85 , equivalent to assumption that no enhancement of concrete strength should be experienced due to containment.

Sections, both circular and rectangular, which have a wall thickness thinner than permitted (Goode 2008) by the local buckling could be used if a factor of 0.75 was applied to the resistance predicted by Eurocode 4 .

The simplified ' $k$ ' factor method and second order analysis of Eurocode 4 showed similar results.

Further investigations, tests, FEM and structural analyses are required.

\section{References}

Baochung, C.; Hiroshi, H. 2003. Eccentricity ratio effect on the behavior of eccentrically loaded CFST columns, in Proc. ASSCCA'03 International Conference Advances in Structures (ASCCS-7), Sydney, Australia, 2003, 973-978.

Benzaid, R.; Chikh, N.; Mesbah, H. 2008. Behaviour of squareconcrete column confined with GFRP composite warp, Journal of Civil Engineering and Management 14(2): 115-120. doi:10.3846/1392-3730.2008.14.6

Eurocode 4, 2005: Design of composite steel and concrete structures - Part 1-1: General Rules and Rules for Buildings. CEN, Brussels.

Goode, C. D. 2008. Composite columns - 1819 tests on concrete-filled steel tube columns compared with Eurocode 4, The Structural Engineer 86(16): 33-38.

Goode, C. D. 2009. ASCCS database of Concrete-Filled Steel Tube Columns [cited 24 July 2009]. Available from Internet: <http://web.ukonline.co.uk/ asccs2>.
Gopal, S. R.; Manoharan, P. D. 2003. Structural behavior of slender columns infilled with fibre reinforced concrete, in Proc. ASSCCA'03 International Conference Advances in Structures (ASCCS-7), Sydney, Australia, 871-875.

Chung, J.; Matsui, C.; Tsuda, K. 2001. Simplified design formula of slender concrete-filled steel tubular beamcolumns, Struct. Eng. and Mechanics 12(1): 71-84.

DL/T5085-1999: Design code for concrete filled steel tubes. China, 1999.

Han, L. H. 2000. The influence of concrete compaction on the strength of concrete filled steel tubes, Advances in Structural Engineering 3(2): 131-137. doi:10.1260/1369433001502076

Han, L-H; Yao, G-H. 2002. Tests on stub columns of concretefilled RHS sections, Journal of Constructional Steelwork 58: 353-372. doi:10.1016/S0143-974X(01)00059-1

Han, L-H.; Yang, Y-F. 2003. Analysis of thin-walled steel RHS columns filled with concrete under long-term sustained loads, Thin-Walled Structures 41: 849-870. doi:10.1016/S0263-8231(03)00029-6

Han, L-H.; Yao, G-H. 2003. Influence of concrete compaction on the strength of concrete-filled steel RHS columns, Journal of Constructional Steel Research 59(6): 751-767. doi:10.1016/S0143-974X(02)00076-7

Han, L.-H.; Yao, G. 2003. Behaviour of concrete-filled hollow structural steel (HSS) columns with pre-load on the steel tubes, Journal of Constructural Steel Research 59(8): 1455-1475. doi:10.1016/S0143-974X(03)00102-0

Han, L-H.; Zhong, T.; Wei, L. 2004. Effects of sustained load on concrete-filled hollow structural steel columns, Journal of Structural Engineering ASCE 9: 1392-1404. doi:10.1061/(ASCE)0733-9445(2004)130:9(1392)

Kudzys, A.; Kvedaras, A. K. 2006. Research on structural resistance and safety of tubular composite members, Mechani$k a$ Issue 5: 5-10.

Kuranovas, A. 2006. Influence of interaction between hollow concrete-filled steel tubes components to their strength, in Proc. of an 8th International Conference on SteelConcrete Composite and Hybrid Structures, Harbin: Harbin Univ. of Science and Technology, 155-167.

Kuranovas, A.; Kvedaras, A. K. 2007. Behaviour of hollowconcrete steel tubular composite elements, Journal of Civil Engineering and Management 13(2): 131-141.

Kuranovas, A.; Kvedaras, A. K. 2007. Centrifugally manufactured hollow concrete-filled steel tubular columns, Journal of Civil Engineering and Management 13(4): 297-306.

Kuranovas A.; Goode, D.; Kvedaras, A. K.; Zhong, S. 2009. Load-bearing capacity of concrete-filled steel columns, Journal of Civil Engineering and Management 15(1): 2133. doi:10.3846/1392-3730.2009.15.21-33

Kvedaras, A. K.; Kudzys, A.; Valiūnas, B. 2009. Reliability verification for composite structures of annular cross section, Mechanics of Composite Materials 45(4): 407-414. doi:10.1007/s11029-009-9094-5

Kvedaras, A. K.; Kudzys, A. 2006. The structural safety of hollow concrete-filled circular steel members, Journal of Constructional Steel Research 62(11): 1116-1122. doi:10.1016/j.jcsr.2006.06.006

Matsui, C., et al. 1995. Slender concrete filled steel tubular columns under combined compression and bending, in Proc. of an 4th Pacific Structural Steel Conference, Vol. 3, Steel-Concrete Composite Structures, 29-36.

Partaukas, N.; Bareišis, J. 2009. The stress state in two-layer hollow cylindrical bars, Mechanika Issue 1: 5-12. 
Soundararajan, A.; Shanmugasundaram, K. 2008. Flexural behaviour of concrete-filled hollow sections beams, Journal of Civil Engineering and Management 14(2): 107 114. doi:10.3846/1392-3730.2008.14.5

Xinbo, M.; Zhang, S.; Goode, C. D. 2006. Comparison of design methods for circular concrete filled steel tube columns in different codes, in Proc of 8th International Conference on Steel-Concrete Composite and Hybrid Structures Harbin: Harbin Univ. of Science and Technology, 30-37.
Yamamoto, T., et al. 2000. Experimental study of scale effects on the compressive behavior of short concrete-filled steel tube columns, in Proc of the United Engineering Foundation Conference on Composite Construction in Steel and Concrete IV (AICE), Banff, Canada, 879-891.

Zhang, S., et al. 2007. Behaviour and strength of circular tube confined reinforced concrete columns, Steel Constructions 2: $36-48$.

Zhong, S. 1999. High-rise buildings of concrete filled steel tubular structures. Heilongjian.

\title{
LIAUNŲ BETONŠERDŽIŲ PLIENINIŲ VAMZDINIŲ KOLONŲ KLUPUMAS
}

\author{
C. D. Goode, A. Kuranovas, A. K. Kvedaras
}

\section{$\mathrm{S}$ a $\mathrm{n} \mathrm{tr}$ a u k a}

Straipsnyje aptariami 1817 betonšerdžių plieninių vamzdinių strypų eksperimentiniai duomenys. Šie duomenys lyginami su rezultatais, gautais remiantis Eurocode 4 pateiktais kompozitinių elementu laikomosios galios nustatymo metodais. Analizuojami tokie betonšerdžių plieninių strypų bandinių tipai: pilnavidurès trumpos arba liaunos apskritojo ir stačiakampio skerspjūvio vamzdinès betonšerdės plieninės kolonos su ju galuose veikiančiu lenkiamuoju momentu arba be jo. Apskritojo skerspjūvio betonšerdžių kolonų bandymų metu gautieji laikomosios galios rezultatai atitinka remiantis Eurocode 4 pateiktais metodais apskaičiuotąsias jų reikšmes. Stačiakampio skerspjūvio betonšerdžių elementų laikomosios galios bandymais rastosios reikšmès labai gerai atitinka teorines reikšmes, kai šerdies betono ritininis stipris nesiekia $75 \mathrm{~N} / \mathrm{mm}^{2}$. Analizuojant nustatyta, kad išankstinis betonšerdžių elementų apkrovimas neturi beveik jokio poveikio elementų laikomajai galiai. Šiame straipsnyje taip pat nagrinejjamas betonšerdžių elementų itempių būvių pasiskirstymas, betono apspaudimo poveikis bei išilginių deformacijų ir ịtempių kreivès.

Reikšminiai žodžiai: kompozitinės konstrukcijos, betonšerdès plieninės vamzdinės kolonos, Eurocode 4, skaičiavimas, lyginimas, liaunumas, klupumas, laikomoji galia, bandymo rezultatai.

Douglas GOODE. PhD, University of Manchester, UK. He is a member of International Association for Steel-Concrete Composite Structures (ASCCS). He is author of biggest database which contains more than 1800 test results of concretefilled steel tubular columns. Research interests: steel, concrete, composite steel and concrete structures.

Artiomas KURANOVAS. PhD student at the Department of Steel and Timber Structures, Vilnius Gediminas Technical University, Lithuania. A graduate of Civil Engineering at Vilnius Gediminas Technical University (2002). MSc of Civil Engineering (2004) at Vilnius Gediminas Technical University. He is a member of the Council on Tall Buildings and Urban Habitat (CTBUH) and the International Association for Steel-Concrete Composite Structures (ASCCS). Research interests: structural mechanics, composite elements and behaviour of their components, engineering software for design of structural elements.

Audronis Kazimieras KVEDARAS. Dr Habil Professor at the Department of Steel and Timber Structures and Director of the Innovatory Scientific Institute of Special Structures “Kompozitas” of Vilnius Gediminas Technical University. He is a member of the International Association for Bridge and Structural Engineering (IABSE) and ASCCS, invited NATO expert (1996, 2000). Research interests: steel, composite steel-concrete and timber-concrete structures. 